CHRONIC OBSTRUCTIVE PULMONARY DISEASE

\title{
Differences in local versus systemic TNF $\alpha$ production in COPD: inhibitory effect of hyaluronan on LPS induced blood cell TNF $\alpha$ release
}

\author{
M A Dentener, R Louis, R H E Cloots, M Henket, E F M Wouters
}

See end of article for authors' affiliations

Correspondence to M A Dentener,

PhD, Department of Respiratory Medicine, University Hospital

Maastricht, P O Box 5800 6202 AZ Maastricht, The Netherlands; Mieke.

Dentener@pul.unimaas.nl

Received

23 September 2005

Accepted

19 February 2006

Published Online First

3 March 2006
Background: Chronic obstructive pulmonary disease (COPD) is characterised by both airway inflammation and systemic changes. To elucidate the relationship between local and systemic inflammation, tumour necrosis factor $\alpha$ (TNF $\alpha$ ) production by sputum cells and blood cells of patients with COPD and controls was compared and the effect of the extracellular matrix compound hyaluronan (HA) on TNF $\alpha$ release was studied.

Methods: Four study groups were included: 10 steroid free COPD patients, 8 steroid treated patients, 10 healthy smokers, and 11 healthy non-smokers. Sputum cells and blood were incubated for 24 hours with or without lipopolysaccharide (LPS) in the absence or presence of HA (122 kDa or HMW fragment). TNF $\alpha$ was measured by ELISA.

Results: Sputum cells produced spontaneously high levels of TNF $\alpha$ but were unresponsive to LPS. Sputum cells from COPD patients (both steroid free and steroid treated) produced significantly less TNF $\alpha$ than cells from healthy non-smoking subjects ( $p=0.017$ and $p=0.001$, respectively). In contrast, blood cells produced TNF $\alpha$ only in response to LPS. No differences were observed in TNF $\alpha$ production by blood cells between the patient groups and the control groups. HA (both fragments) partially blocked LPS $(1 \mathrm{ng} / \mathrm{ml}$ ) induced TNF $\alpha$ release by blood cells from all study groups, whereas TNF $\alpha$ production by sputum cells was not influenced by HA.

Conclusion: These data indicate a difference between local and systemic TNF $\alpha$ production. Sputum cells of patients with COPD produced less TNF $\alpha$ than controls, which could contribute to impaired local defence. An inhibitory effect of HA on TNF $\alpha$ release in blood cells was observed which was similar in both patients and controls.

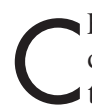
hronic obstructive pulmonary disease (COPD) is complex heterogeneous respiratory disease characterised by the progressive development of airflow limitation that is largely irreversible. Airway inflammation is a key feature of COPD and is reasoned to play a pathogenic role. ${ }^{1}$ Influx of neutrophils and macrophages in the airway wall is related to airway obstruction in patients with severe COPD. ${ }^{2}$ Moreover, infiltration of CD8+ lymphocytes has been seen throughout the whole lung which is inversely related to forced expiratory volume in 1 second $\left(\mathrm{FEV}_{1}\right) \cdot{ }^{3}{ }^{4}$ Progression of the disease is also associated with the presence of polymorphonuclear cells, macrophages, CD4 cells, and lymphocyte subtypes in the small airways. ${ }^{5}$ These inflammatory cells may be an important source of inflammatory mediators and proteases which can enhance inflammatory processes in COPD. In induced sputum from patients with COPD, increased levels of the chemokine interleukin (IL)-8, the pro-inflammatory cytokine tumour necrosis factor $(\mathrm{TNF}) \alpha$, and its soluble receptors (sTNF-R) have been observed. ${ }^{67}$ Enhanced levels of inflammatory markers such as TNF $\alpha$ and the acute phase protein C-reactive protein (CRP) have also been reported in the circulation, ${ }^{78}$ indicating a systemic inflammatory reaction. A clear association has been shown between circulating inflammatory mediators and other systemic effects of COPD such as tissue wasting and cardiovascular morbidity. ${ }^{9}$ Very little is known about the origin of the systemic inflammation in COPD. In a previous study we showed that levels of sputum and circulating inflammatory markers were not correlated, suggesting that the systemic inflammation in COPD is not due to an overflow of inflammatory mediators from the pulmonary compartment. ${ }^{7}$ In order to further elucidate the relationship between local and systemic inflammation, the production of TNF $\alpha$ by sputum cells and blood cells of COPD patients (either steroid free or steroid treated) versus smoking and non-smoking control subjects was analysed.

Chronic pulmonary inflammation and lung injury are associated with damage, repair and remodelling of the extracellular matrix (ECM). Recently, we have demonstrated enhanced levels of the ECM compound hyaluronan (HA) in sputum supernatant of COPD patients. ${ }^{10}$ Moreover, in circulation of inflammatory diseases such as rheumatoid arthritis elevated HA levels were reported. ${ }^{11} \mathrm{HA}$ is known to have pro-inflammatory potential when present in small fragments, and to be anti-inflammatory in high molecular size. ${ }^{12}$ Therefore, we also analysed the effect of HA on sputum and blood cell TNF $\alpha$ production and compared responsiveness of COPD versus control subjects to this ECM compound.

\section{METHODS}

Study groups

COPD patients

Eighteen patients with moderate to severe COPD were recruited from the outpatient clinic and rehabilitation centre CHU-Sart-Tilman. A summary of their characteristics is shown in table 1. COPD was diagnosed according to the GOLD criteria-that is, post-bronchodilator $(400 \mu \mathrm{g}$ inhaled sabutamol) $\mathrm{FEV}_{\mathrm{l}} / \mathrm{FVC}$ ratio $<70 \%$. All the COPD subjects

Abbreviations: COPD, chronic obstructive pulmonary disease; $\mathrm{FEV}_{1}$, forced expiratory volume in 1 second; HA, hyaluronan; IL, interleukin; LPS, lipopolysaccharide; TNF $\alpha$, tumour necrosis factor $\alpha$ 
Table 1 Demographic and functional characteristics of study groups

\begin{tabular}{|c|c|c|c|c|}
\hline & \multicolumn{2}{|l|}{ Control subjects } & \multicolumn{2}{|l|}{ COPD patients } \\
\hline & $\begin{array}{l}\text { Non-smoking } \\
(\mathrm{n}=11)\end{array}$ & $\begin{array}{l}\text { Smoking } \\
(\mathrm{n}=10)\end{array}$ & $\begin{array}{l}\text { Steroid free } \\
(n=10)\end{array}$ & $\begin{array}{l}\text { Steroid treated } \\
(n=8)\end{array}$ \\
\hline $\operatorname{Sex}(M / F)$ & $6 / 5$ & $7 / 3$ & $8 / 2$ & $6 / 2$ \\
\hline Age & $53(42-69)$ & $51(41-63)$ & $67(38-74)^{*} \dagger$ & $58(45-78)$ \\
\hline \multicolumn{5}{|l|}{ Smoking behaviour } \\
\hline Non/ex/current & $11 / 0 / 0$ & $0 / 4 / 6^{*}$ & $0 / 2 / 8^{*}$ & $0 / 6 / 2^{*}$ \\
\hline Pack-years & 0 & $23(13-44)^{*}$ & $45(24-56)^{*} \dagger$ & $47(15-60)^{*} \dagger$ \\
\hline $\mathrm{FEV}_{1}(\mathrm{ml})$ & $3760(2130-5670)$ & 3465 (2480-4840) & $1215(890-3010)^{*} \dagger$ & $1155(600-1410)^{*}+$ \\
\hline $\mathrm{FEV}_{1}$ (\% predicted) & $109(94-133)$ & $99(87-121)$ & $41(29-75)^{*} \dagger$ & $35(23-62)^{*} \dagger$ \\
\hline $\mathrm{FVC}(\mathrm{ml})$ & $4690(2620-6550)$ & $4260(2940-7030)$ & $2525(1530-5350)^{*} \dagger$ & $1675(1040-3090)^{*} \dagger$ \\
\hline FVC (\% predicted) & $120(91-127)$ & $100(89-143)$ & $59(44-107)^{*} \dagger$ & $48(29-72)^{*}+$ \\
\hline $\mathrm{FEV}_{1} / \mathrm{FVC}(\%)$ & $80(71-90)$ & $79(71-90)$ & $53(43-62)^{*} \dagger$ & $60(42-68)^{*} \dagger$ \\
\hline RV (\% predicted) & ND & ND & $215(141-242)$ & 227 (189-242) \\
\hline TLC (\% predicted) & ND & ND & $109(104-146)$ & $120(100-131)$ \\
\hline BMI & $23.4(21.2-31.6)$ & $24.3(21.2-31.6)$ & $25.6(21.0-29.4)$ & $25.9(16.5-25.9)$ \\
\hline
\end{tabular}

Values are expressed as median (range) or as absolute numbers.

$\mathrm{FEV}_{1}$, forced expiratory volume in 1 second; FVC, forced vital capacity; RV, residual volume; TLC, total lung capacity; BMI, body mass index; ND, not determined. Differences between groups were tested using the Kruskal-Wallis $\mathrm{H}$ test and, if appropriate $(\mathrm{p}<0.05)$, subsequent analysis of subgroups was performed using Mann-Whitney $U$ test or the Fisher's exact test.

${ }^{*} \mathrm{p}<0.05 v$ non-smoking controls; $\mathrm{t} p<0.05 v$ smoking controls.

were life long heavy smokers (more than 15 pack years). They were all using long acting bronchodilators including tiotropium, formoterol, or salmeterol. Eight of the 18 patients were receiving inhaled corticosteroids ( $1000 \mu \mathrm{g}$ fluticasone or $800 \mu \mathrm{g}$ budesonide/day) and form the steroid treated group; the other patients were steroid free.

\section{Control subjects}

Twenty one control subjects were recruited through advertisement from the hospital staff of CHU Sart Tilman. Care was taken to recruit patients who matched the patients with COPD with respect to age and sex. Ten of the control subjects were current smokers with a mean of 23 pack years (table 1).

The protocol was approved by the local ethical committee and volunteers gave their signed informed consent.

\section{Sputum induction and processing}

After premedication with $400 \mu \mathrm{g}$ inhaled salbutamol, sputum was induced by inhalation of a hypertonic saline solution ( $\mathrm{NaCl} 4.5 \%$ ) when $\mathrm{FEV}_{1}$ was $>65 \%$ predicted and by isotonic saline $\left(\mathrm{NaCl} 0.9 \%\right.$ ) when $\mathrm{FEV}_{1}$ was $<65 \%$ predicted. In order to improve bronchoprotection, additional amounts of salbutamol were delivered during the saline nebulisation itself as previously described. ${ }^{13}$ Saline aerosols were delivered by an ultrasonic nebuliser (Ultra-Neb 2000, De Vilbiss, Somerset, USA) with an output of $1.5 \mathrm{ml} / \mathrm{min}$. Each subject inhaled the aerosol for three consecutive periods of 5 minutes for a total time of 15 minutes. For safety reasons, the $\mathrm{FEV}_{1}$ was monitored every 5 minutes and the induction stopped when $\mathrm{FEV}_{1}$ fell by more than $20 \%$ from baseline.

Whole sputum was collected in a $50 \mathrm{ml}$ polypropylene tube, weighed, and diluted 1:4 with phosphate buffered saline without $\mathrm{Ca}^{2+}$ and $\mathrm{Mg}^{2+}$ (DPBS), vortexed for 30 seconds and centrifuged at $800 \mathrm{~g}$ for 10 minutes at $4^{\circ} \mathrm{C}$. The supernatant and cell pellet diluted in $20 \mathrm{ml}$ of DPBS were filtered separately on double thickness gauze. The supernatant was stored at $-80^{\circ} \mathrm{C}$ until analysed for TNF $\alpha$ and IL-8. Cells were washed and suspended in $1 \mathrm{ml}$ DPBS for total cell counts using a manual haemocytometer. The differential cell count was performed on cytospins stained with Diff-Quick by counting 500 cells under a light microscope.

\section{Sputum cell and whole blood cell stimulation}

Sputum cells were obtained as reported above. In order to perform blood cell stimulation, heparinised whole blood was collected and diluted $1: 20$. Both sputum cells $\left(4 \times 10^{5}\right.$ non-squamous cells $/ \mathrm{ml}$ ) and whole blood were dissolved in RPMI-1640, supplemented with penicillin and streptomycin and $5 \%$ of heat inactivated fetal calf serum (FCS), and incubated for 24 hours at $37^{\circ} \mathrm{C}$ in plates coated with antiTNF $\alpha$ antibody as described below. Stimulation was performed in the absence or presence of lipopolysaccharide (LPS E coli, Sigma, St Louis, MO, USA) and in the absence or presence of HA $122 \mathrm{kDa}$ (Polytech, Trieste, Italy) or HA $>10^{6}$ Da (Ostenil; Chemedica AG, München, Germany), the latter being indicated as high molecular weight (HMW) HA. Both HA compounds were checked for endotoxin content using LAL assay (detection level of $1 \mathrm{pg} / \mathrm{ml}$ ), which was not found.

\section{TNF $\alpha$ assay}

TNF $\alpha$ produced by sputum cells and blood cells was measured by a modified two-step sandwich type immunoassay (immunotrapping technique). The antibodies and standards were purchased from Biosource (Fleurus, Belgium). Cells were stimulated in apyrogen microwells (Nunc Maxisorp, VWR, Belgium) coated with anti-TNF $\alpha$ antibodies (Ms X Hu TNF $\alpha$ clone 68B 6A3, Ms IgGl and 68B 2B3, Ms IgG2) and, in parallel, recombinant TNF $\alpha$ standards were added to the wells. After 24 hours of incubation the wells were washed six times and incubated for 2 hours with a biotinylated anti-TNF $\alpha$ antibody (Ms X Hu TNF $\alpha$ biotin clone 68B 3C5, Ms IgGl) followed by streptavidin-horseradish peroxidase. The substrate chromogen solution TMB was used and absorbance was measured at $450 \mathrm{~nm}$. Sensitivity was 10$15 \mathrm{pg} / \mathrm{ml}$ for the immunotrapping technique applied to the cell culture. The Biosource assay has been validated for conditioned medium but not for serum; this, together with improved sensitivity, led us to use the Quantikine high sensitivity R\&D TNF $\alpha$ immunoassay (detection level $0.5 \mathrm{pg}$ / $\mathrm{ml}$ ) to measure TNF $\alpha$ in the serum samples. The Pelikine compact human TNF $\alpha$ assay (Sanquin, Amsterdam, the Netherlands) was used to detect TNF $\alpha$ in the sputum supernatant (detection limit $1 \mathrm{pg} / \mathrm{ml}$ ).

\section{IL-8 assay}

IL-8 levels were determined using specific sandwich ELISA as described by Bouma and colleagues ${ }^{14}$ (detection limit 80 pg/ml).

\section{Statistical analysis}

The results are presented as median (range). Inter-group comparisons were performed using the Kruskal-Wallis H test; 
Table 2 Sputum characteristics

\begin{tabular}{|c|c|c|c|c|}
\hline & \multicolumn{2}{|l|}{ Control subjects } & \multicolumn{2}{|l|}{ COPD patients } \\
\hline & $\begin{array}{l}\text { Non-smoking } \\
(\mathrm{n}=9)\end{array}$ & $\begin{array}{l}\text { Smoking } \\
(\mathrm{n}=10)\end{array}$ & $\begin{array}{l}\text { Steroid free } \\
(n=9)\end{array}$ & $\begin{array}{l}\text { Steroid treated } \\
(n=8)\end{array}$ \\
\hline Sputum weight (g) & $4.3(2.5-7.5)$ & $4.4(1.0-7.4)$ & $3.1(1.7-9.1)$ & $2.5(1.4-4.9)$ \\
\hline Squamous cells (\%) & $18(6-30)$ & $12.5(3-54)$ & $19(9-47)$ & $13(0-45)$ \\
\hline Viability (\%) & $59(27-79)$ & $61(39-77)$ & $75(25-87)$ & $74(37-90)$ \\
\hline $10^{6}$ cells/g & $0.5(0.3-1.8)$ & $0.6(0.1-2.4)$ & $0.9(0.3-3.2)$ & $1.2(0.5-11.7)$ \\
\hline \multicolumn{5}{|l|}{ Neutrophils } \\
\hline$\%$ & $52.0(16.0-77.6)$ & $38.3(4.6-87.0)$ & $57.6(12.0-91.4)$ & $87.3(5.2-95.0)$ \\
\hline$\times 10^{6} / \mathrm{g}$ & $0.29(0.08-1.41)$ & $0.19(0.02-0.81)$ & $0.47(0.11-2.74)$ & $1.03(0.02-10.67)$ \\
\hline \multicolumn{5}{|l|}{ Macrophages } \\
\hline$\%$ & $35.8(14.0-58.4)$ & $35.4(8.0-74.8)$ & $33.8(6.6-77.0)$ & $8.3(3.6-62.4)$ \\
\hline$\times 10^{6} / \mathrm{g}$ & $0.29(0.07-0.65)$ & $0.35(0.04-1.8)$ & $0.13(0.06-0.87)$ & $0.23(0.04-0.56)$ \\
\hline \multicolumn{5}{|l|}{ Lymphocytes } \\
\hline$\%$ & $2.8(0.2-4.8)$ & $1.9(02-10.0)$ & $1.4(0.0-5.0)$ & $1.2(0.0-4.6)$ \\
\hline$\times 10^{6} / \mathrm{g}$ & $0.01(0.00-0.04)$ & $0.01(0.00-0.24)$ & $0.01(0.00-0.05)$ & $0.015(0.00-0.12)$ \\
\hline \multicolumn{5}{|l|}{ Eosinophils } \\
\hline$\%$ & $0.0(0.0-3.6)$ & $0.1(0.0-6.2)$ & $0.0(0.0-2.0)$ & $0.3(0.0-49.6)$ \\
\hline$\times 10^{6} / \mathrm{g}$ & $0.0(0.0-0.02)$ & $0.0(0.0-0.09)$ & $0.0(0.0-0.02)$ & $0.005(0.0-0.35)$ \\
\hline \multicolumn{5}{|l|}{ Epithelial cells } \\
\hline & $9.8(0.8-28.2)$ & $10.2(1.4-66.4)$ & $5.8(1.0-39.4)$ & $1.1(0.0-31.4)$ \\
\hline$\times 10^{6} / \mathrm{g}$ & $0.06(0.0-0.17)$ & $0.11(0.01-0.35)$ & $0.06(0.02-0.83)$ & $0.035(0.0-0.19)$ \\
\hline IL-8 positive samples & $5 / 9$ & $8 / 10$ & $9 / 9$ & $8 / 8$ \\
\hline IL-8 (ng/ml)‡ & $0.11(0.08-2.81)$ & $0.42(0.08-4.59)$ & $1.17(0.28-25.0)^{*}$ & $5.75(0.91-14.40)^{*} \dagger$ \\
\hline TNF $\alpha$ positive samples & $2 / 9$ & $4 / 10$ & $4 / 10$ & $5 / 8$ \\
\hline $\mathrm{TNF} \alpha(\mathrm{pg} / \mathrm{ml}) \ddagger$ & $1.0(1.0-3.3)$ & $1.0(1.0-8.9)$ & $1.0(1.0-25.8)$ & $4.5(1.0-307.8)$ \\
\hline
\end{tabular}

Values are expressed as median (range).

Differences between groups were tested using the Kruskal-Wallis $\mathrm{H}$ test and, if appropriate $(\mathrm{p}<0.05)$, subsequent analysis of subgroups was performed by the Mann-Whitney $U$ test.

${ }^{*} \mathrm{p}<0.05 v$ non-smoking controls; $\mathrm{tp}<0.05 v$ smoking controls.

†Statistical differences between study groups were calculated based on all samples. In case of non-detectable samples, the lower detection level of the assay was used (80 pg/ml for IL-8, $1 \mathrm{pg} / \mathrm{ml}$ for TNF $\alpha$ ).

if differences were present $(\mathrm{p}<0.05)$, further analysis of subsets of groups were performed using the Mann-Whitney $\mathrm{U}$ test or the Fisher's exact test (to compare categorical variables). To test the effect of LPS on TNF $\alpha$ production and to analyse the effect of HA on spontaneous and LPS induced $\mathrm{TNF} \alpha$ release, intra-groups comparisons were performed by the Friedman test and, if appropriate (at $\mathrm{p}<0.05$ ), by a paired Wilcoxon rank sum test. Correlations between parameters were evaluated using Spearman's rank correlation analysis.

Statistical Package for Social Sciences (SPSS) Version 12.0 for Windows (SPSS Inc, Chicago, IL, USA) was used for statistical analysis, a $p$ value of $<0.05$ denoting the presence of a significant statistical difference.

\section{RESULTS}

\section{Patient characteristics}

The characteristics of the patients with COPD and the healthy control subjects are summarised in table 1. All four study groups consisted mostly of men and all COPD patients were current or ex-smokers. In both control groups of nonsmokers and healthy smokers, all pulmonary function parameters were in the normal range which were significantly reduced in the COPD study groups. The FVC was low in the COPD patients, but this was explained by the importance of air trapping as reflected by high values of residual volume (RV) and total lung capacity (TLC). No differences in lung function were found between steroid treated and steroid free patients. Furthermore, all four study groups had comparable body mass index.

\section{TNF $\alpha$ production in sputum cells}

Sputum induction was performed successfully in the four study groups. Although COPD patients tended to have higher median total cell counts and neutrophil numbers together with reduced numbers of macrophage, the differences between the study groups were not significant (table 2). IL8 was significantly enhanced in the sputum of patients with
COPD (table 2) and, when analysed in the whole group, correlated significantly with the neutrophil count $(\mathrm{n}=36$, $r=0.399, \mathrm{p}=0.021$; data not shown). TNF $\alpha$ was detectable only in part of the sputum samples and levels of TNF $\alpha$ did not differ between study groups (table 2 ).

In order to analyse local TNF $\alpha$ production, sputum cells were cultured for 24 hours in the absence and presence of LPS, a bacterial cell wall constituent known to have strong inflammatory capacity. Sputum cells spontaneously produced considerable amounts of TNF $\alpha$ (fig 1). TNF $\alpha$ production by cells from COPD patients (both study groups) was significantly lower than for non-smoking control subjects and tended to be different from smoking controls (steroid free COPD $v$ smoking controls, $\mathrm{p}=0.08$; steroid treated COPD $v$ smoking controls, $p=0.1$ ). No relationship was seen between the viability of sputum cells and spontaneous TNF $\alpha$ production ( $\mathrm{n}=36, r=0.124, \mathrm{p}=0.47)$. The presence of LPS (either $1 \mathrm{ng} / \mathrm{ml}$ or $10 \mathrm{ng} / \mathrm{ml}$ ) did not affect spontaneous TNF $\alpha$ production for all groups, with the exception of LPS $1 \mathrm{ng} /$ $\mathrm{ml}$ in the non-smoking control subjects $(\mathrm{p}=0.022$, fig 1$)$.

\section{TNF $\alpha$ production in blood cells}

Significantly enhanced leucocyte numbers were present in the blood of both COPD subgroups compared with controls, which was mainly due to increased amounts of neutrophils (table 3). A negative correlation between blood neutrophil number and $\mathrm{FEV}_{1} \%$ predicted was found for the whole study group ( $\mathrm{n}=39, r=-0.656, \mathrm{p}<0.001$ ) which was still present after analysis of patient and control subgroups (fig 2). Low levels of TNF $\alpha$ could be detected in the serum of all subjects, but no discrimination between study groups could be made based on the concentration of this cytokine (table 3 ).

In contrast to sputum, culture of blood cells did not result in spontaneous production of TNF $\alpha$. The release of TNF $\alpha$ was induced by LPS in a concentration dependent manner (fig 3). No differences were seen in LPS ( $1 \mathrm{ng}$ and $10 \mathrm{ng} / \mathrm{ml}$ ) induced $\mathrm{TNF} \alpha$ release between study groups. Since TNF $\alpha$ release was 


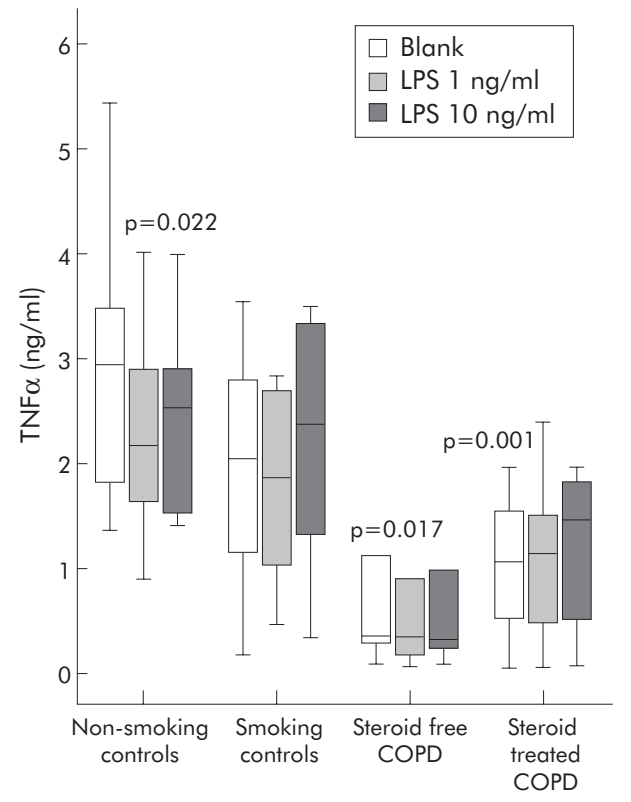

Figure 1 TNF $\alpha$ production by sputum cells of COPD patients and control subjects. TNF $\alpha$ production by sputum cells ( 20000 cells/well) was measured by a dynamic immunoassay during a 24 hour culture period. Cells were incubated in RPMI $5 \%$ fetal calf serum without LPS (blank) or with LPS $1 \mathrm{ng} / \mathrm{ml}$ or $10 \mathrm{ng} / \mathrm{ml}$. Data are presented as median with interquartile range (box) and range (whiskers) for 10 non-smoking controls, 10 smoking controls, 9 steroid free COPD patients, and 8 steroid treated COPD patients. The $p$ values indicate differences compared with spontaneous TNF $\alpha$ production by sputum cells from nonsmoking controls.

measured in 1:20 diluted whole blood and leucocyte counts differed between groups, TNF $\alpha$ release per 20000 leucocytes was calculated which did not result in differences between study subjects (data not shown).

\section{Effect of HA on TNF $\alpha$ production by sputum and blood cells}

Since the extracellular matrix compound HA has been reported to modulate inflammatory reactions, the effect of
HA on TNF $\alpha$ production by blood and sputum cells from patients and control subjects was analysed. Neither LMW HA ( $122 \mathrm{kDa})$ nor HMW HA $\left(>10^{3} \mathrm{kDa}\right)$ had any effect on spontaneous TNF $\alpha$ production in blood (table 4), but both fragments partially blocked $\mathrm{TNF} \alpha$ release by blood cells induced by LPS $1 \mathrm{ng} / \mathrm{ml}$ in all study groups (table 4 ). This inhibition was comparable for all three concentrations of HA tested ( $1 \mu \mathrm{g} / \mathrm{ml}, 10 \mu \mathrm{g} / \mathrm{ml}$ and $100 \mu \mathrm{g} / \mathrm{ml}$; data not shown). The reduction in $\mathrm{TNF} \alpha$ release by HA was not present when blood cells were stimulated with LPS $10 \mathrm{ng} / \mathrm{ml}$, with the exception of the HMW HA fragments which lowered TNF $\alpha$ release in steroid free COPD patients (table 4). No constitutive effect of either HA fragment was observed on spontaneous or LPS induced TNF $\alpha$ release by sputum cells (data not shown).

\section{DISCUSSION}

This study shows a clear difference between TNF $\alpha$ production in sputum cells and in blood cells in patients with COPD and control subjects. Sputum cells produced constitutively high levels of $\mathrm{TNF} \alpha$, which was significantly lower in COPD patients than in controls. LPS had no effect on sputum cell $\mathrm{TNF} \alpha$ production. In contrast, blood cells produced no TNF $\alpha$ spontaneously, and there was a significant increase in TNF $\alpha$ production in response to LPS, which did not differ between the study groups. Further indications for discrepancies between local and systemic inflammation were obtained by the observation that the extracellular matrix compound HA partially blocked LPS induced TNF $\alpha$ release by blood cells but did not affect $\mathrm{TNF} \alpha$ production by sputum cells. No indication for altered responsiveness of cells of COPD patients towards HA was obtained.

Steroids are known to have anti-inflammatory effects ex vivo, but the effect of these drugs on COPD inflammation are not so clear. Inhaled steroids have been shown to reduce neutrophil cell counts in sputum, ${ }^{15}$ but other studies could not confirm this effect on airway inflammation. ${ }^{16}$ In the present study no differences in lung function and in local and systemic $\mathrm{TNF} \alpha$ release were seen between subgroups of patients treated with inhaled steroids and steroid free patients, indicating that steroids may not have a dramatic effect on TNF $\alpha$ production ex vivo. Nevertheless, since this study is cross sectional, intervention studies are required to confirm this conclusion.

Table 3 Blood differential cell count and TNF $\alpha$ level

\begin{tabular}{|c|c|c|c|c|}
\hline & \multicolumn{2}{|l|}{ Control subjects } & \multicolumn{2}{|l|}{ COPD patients } \\
\hline & $\begin{array}{l}\text { Non-smoking } \\
(n=11)\end{array}$ & $\begin{array}{l}\text { Smoking } \\
(n=10)\end{array}$ & $\begin{array}{l}\text { Steroid free } \\
(n=10)\end{array}$ & $\begin{array}{l}\text { Steroid treated } \\
(n=8)\end{array}$ \\
\hline $\begin{array}{l}\text { Leucocytes }\left(\times 10^{6} / \mathrm{ml}\right) \\
\text { Neutrophils }\end{array}$ & $5.7(4.4-8.7)$ & $7.2(4.6-10.4)$ & $9.1(7.1-13.9)^{*} \dagger$ & $8.7(6.1-16.8)^{*} \dagger$ \\
\hline$\%$ & $49.6(44.4-73.0)$ & $57.1(45.4-70.8)$ & $61.8(49.9-68.4)^{*}$ & $69.9(54.3-85.5)^{*} \dagger$ \\
\hline$\times 10^{6} / \mathrm{ml}$ & $3.3(2.13-5.5)$ & $4.1(2.1-6.4)$ & $5.9(3.6-8.7)^{*}$ & $6.7(3.7-13.6)^{*} \dagger$ \\
\hline \multicolumn{5}{|l|}{ Lymphocytes } \\
\hline$\%$ & $\begin{array}{l}36.5(17.8-42.7) \\
2.1(1.3-3.5)\end{array}$ & $\begin{array}{l}32.6(18.8-39.9) \\
2.0(1.3-3.3)\end{array}$ & $\begin{array}{l}27.3(19.8-39.9)^{*} \\
2.6(1.5-3.7)\end{array}$ & $\begin{array}{l}20.4(9.1-33.7)^{*} \dagger \\
1.8(0.8-2.7)\end{array}$ \\
\hline \multicolumn{5}{|l|}{ Monocytes } \\
\hline$\%$ & $5.7(4.1-9.9)$ & $6.3(3.5-8.7)$ & $6.4(4.3-8.1)$ & $5.6(3.3-8.7)$ \\
\hline$\times 10^{6} / \mathrm{ml}$ & $0.4(0.3-0.7)$ & $0.4(0.3-0.6)$ & $0.6(0.3-1.1)^{*} \dagger$ & $0.5(0.3-1.0)$ \\
\hline \multicolumn{5}{|l|}{ Eosinophils } \\
\hline$\%$ & $2.4(0.9-4.2)$ & $1.7(0.6-4.1)$ & $2.5(0.8-7.6)$ & $1.7(0.0-7.8)$ \\
\hline$\times 10^{6} / \mathrm{ml}$ & $0.1(0.1-0.3)$ & $0.1(0.1-0.3)$ & $0.2(0.1-0.5)$ & $0.2(0.0-0.9)$ \\
\hline \multicolumn{5}{|l|}{ Basophils } \\
\hline$\%$ & $0.7(0.4-1.0)$ & $0.7(0.4-1.3)$ & $0.6(0.3-0.9)$ & $0.4(0.0-1.2)$ \\
\hline$\times 10^{6} / \mathrm{ml}$ & $0.04(0.02-0.06)$ & $0.05(0.02-0.07)$ & $0.05(0.03-0.1)$ & $0.03(0.0-0.14)$ \\
\hline $\mathrm{TNF} \alpha(\mathrm{pg} / \mathrm{ml})$ & $3.5(1.7-9.6)$ & $3.4(2.6-3.7)$ & $3.8(2.5-6.1)$ & $3.6(2.5-4.9)$ \\
\hline
\end{tabular}

Values are expressed as median (range).

Differences between groups were tested using the Kruskal-Wallis $\mathrm{H}$ test and, if appropriate $(\mathrm{p}<0.05)$, subsequent analysis of subgroups was performed by the Mann-Whitney U test.

${ }^{*} \mathrm{p}<0.05 v$ non-smoking controls; $\mathrm{tp}<0.05 v$ smoking controls. 
A

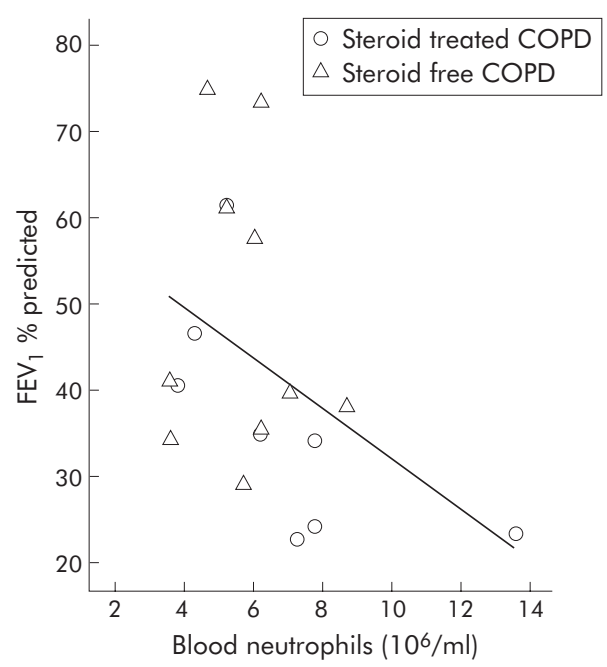

B

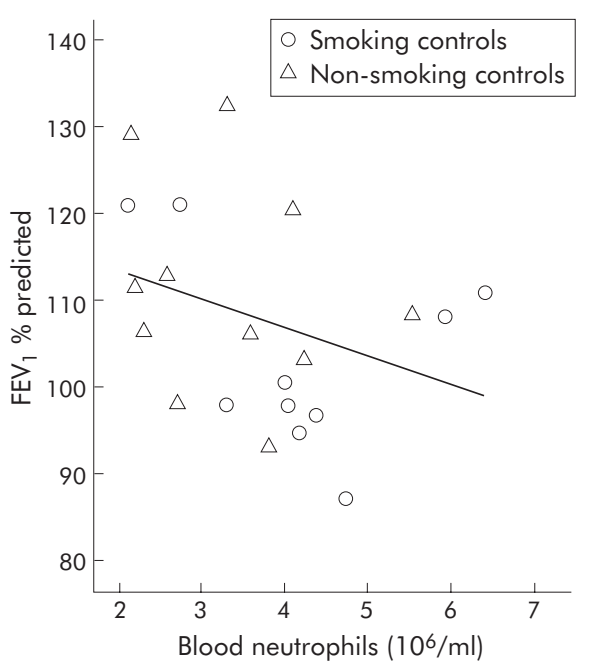

Figure 2 Relationship between number of neutrophils in the blood and $\mathrm{FEV}_{1} \%$ predicted. A significant negative relationship was seen between the absolute number of neutrophils in peripheral blood and severity of airway obstruction as assessed by FEV $\%$ predicted in both (A) patients with COPD $(n=18, r=-0.489, p=0.039)$ and $(B)$ control subjects $(n=21, r=-0.438, p=0.047)$.

Sputum neutrophilia is generally accepted as a characteristic feature of COPD. ${ }^{6}{ }^{17}$ Although there was a tendency in this study towards enhanced neutrophil numbers and a reduced macrophage count in patients, no significant differences in differential cell counts were seen between patients with COPD and control subjects. This could be due to the relatively small size of the study groups analysed. In addition, care has been taken to match control subjects with respect to age, since Thomas et $a l^{18}$ found that the induced sputum neutrophil count increased significantly with age.

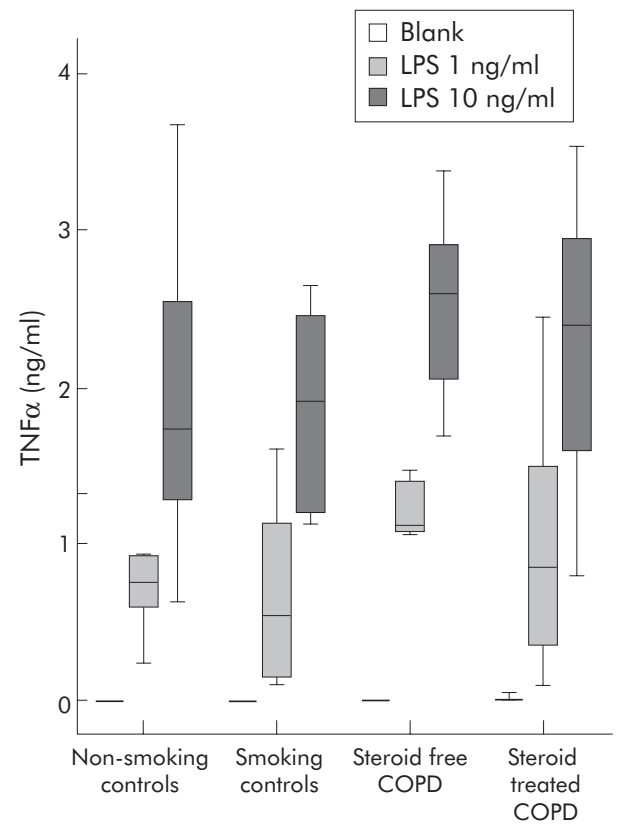

Figure 3 TNF $\alpha$ production by blood cells of COPD patients and control subjects. Heparinised whole blood was diluted 1:20 in RPMI 5\% fetal calf serum and TNF $\alpha$ production was measured by a dynamic immunoassay during a 24 hour culture period. Cells were incubated without LPS (blank) or with LPS $1 \mathrm{ng} / \mathrm{ml}$ or $10 \mathrm{ng} / \mathrm{ml}$. Data are presented as median with interquartile range (box) and range (whiskers) for 11 non-smoking controls, 10 smoking controls, 9 steroid free COPD patients, and 8 steroid treated COPD patients.
The relatively high neutrophil number observed in controls in this study compared with other studies ${ }^{6}{ }^{17}$ may therefore be due to the older age of the controls, and could be the reason for the absence of significantly enhanced neutrophilia in the sputum of patients with COPD. However, raised sputum IL-8 levels-another characteristic of $\mathrm{COPD}^{6}{ }^{7}$-were found in our patient group and correlated with the neutrophil counts. Sputum TNF $\alpha$ was detectable only in part of the samples and did not discriminate between study groups; this is similar to previously published findings, ${ }^{719}$ although some authors also found raised TNF $\alpha$ levels in patients with COPD. ${ }^{6}$ This discrepancy could be due to differences in the severity of the COPD patients studied or to technical aspects such as the method of sputum processing or the TNF $\alpha$ assay used.

In order to study local TNF $\alpha$ production we used ex vivo sputum cell culture which we have previously shown is a suitable model for the study of airway cytokine production. ${ }^{20}$ High constitutive TNF $\alpha$ production by sputum cells was observed, which was significantly reduced in COPD patients compared with control subjects. The contrast between high $\mathrm{TNF} \alpha$ production ex vivo and the low TNF $\alpha$ sputum levels observed in this study suggests either that the in vivo produced TNF $\alpha$ is immediately captured or consumed or, alternatively, that in vivo factors are present which modulate local TNF $\alpha$ production and are absent from in vitro cell cultures. Moreover, since this study was performed on a total cell population, further studies are needed to elucidate which sputum cells are the main producers of TNF $\alpha$ during culture ex vivo and to get more insight into the underlying mechanisms for the observed differences between COPD patients and control subjects.

Contrary to our findings, Profita et $a l^{21}$ showed enhanced TNF $\alpha$ production by sputum cells of patients with COPD. They found differences in the macrophage and neutrophil counts between patients and controls which could account for the discrepancy in the results. However, our data suggesting suppression of inflammatory potential in COPD are supported by the observation of reduced cytokine production by primary bronchial epithelial cells of COPD patients. ${ }^{22}$ The inflammatory response is critical to control the growth of pathogenic micro-organisms, a process in which $\mathrm{TNF} \alpha$ can play a central role by directly activating macrophages and neutrophils. Reduced production of TNF $\alpha$ by 
Table 4 Effect of HA on spontaneous and LPS stimulated TNF $\alpha$ release in blood cells

\begin{tabular}{|c|c|c|c|c|c|}
\hline & & \multicolumn{2}{|l|}{ Control subjects } & \multicolumn{2}{|l|}{ COPD patients } \\
\hline & & $\begin{array}{l}\text { Non-smoking } \\
(\mathrm{n}=11)\end{array}$ & $\begin{array}{l}\text { Smoking } \\
(\mathrm{n}=10)\end{array}$ & $\begin{array}{l}\text { Steroid free } \\
(n=9)\end{array}$ & $\begin{array}{l}\text { Steroid treated } \\
(n=8)\end{array}$ \\
\hline LPS 0 & $\begin{array}{l}\text { None } \\
\text { HA } 122 \mathrm{kDa} \\
\mathrm{HA}>10^{3} \mathrm{kDa}\end{array}$ & $\begin{array}{l}<10(<10-21) \\
<10(<10-19) \\
<10(<10-15)\end{array}$ & $\begin{array}{l}<10(<10-22) \\
<10(<10-14) \\
<10(<10-29)\end{array}$ & $\begin{array}{l}<10(<10-57) \\
<10(<10-27) \\
<10(<10-37)\end{array}$ & $\begin{array}{l}<10(<10-47) \\
<10(<10-25) \\
<10(<10-105)\end{array}$ \\
\hline LPS $1 \mathrm{ng} / \mathrm{ml}$ & $\begin{array}{l}\text { None } \\
\mathrm{HA} 122 \mathrm{kDa} \\
\mathrm{HA}>10^{3} \mathrm{kDa}\end{array}$ & $\begin{array}{l}738(125-3172) \\
496(16-1916)^{*} \\
466(10-2305)^{*}\end{array}$ & $\begin{array}{l}533(98-1607) \\
189(24-1547)^{*} \\
122(37-1784)^{*}\end{array}$ & $\begin{array}{l}1117(96-3057) \\
859(74-2684)^{*} \\
928(117-2840)^{*}\end{array}$ & $\begin{array}{l}829(86-2468) \\
404(10-1433)^{*} \\
558(41-1783)^{*}\end{array}$ \\
\hline LPS $10 \mathrm{ng} / \mathrm{ml}$ & $\begin{array}{l}\text { None } \\
\mathrm{HA} 122 \mathrm{kDa} \\
\mathrm{HA}>10^{3} \mathrm{kDa}\end{array}$ & $\begin{array}{l}1677(625-3681) \\
1501(520-3513) \\
1386(421-3214)\end{array}$ & $\begin{array}{l}1902(1110-2654) \\
1654(540-2696) \\
1708(908-2606)\end{array}$ & $\begin{array}{l}2619(1694-3386) \\
2534(1151-3760) \\
2545(1428-3225) \dagger\end{array}$ & $\begin{array}{l}2405(794-3543) \\
2296(559-3080) \\
2477(828-3264)\end{array}$ \\
\hline
\end{tabular}

LPS, lipopolysaccharide; HA, hyaluronan.

Values are expressed as median (range).

TNF $\alpha$ was measured by ELISA and expressed in $\mathrm{pg} / \mathrm{ml}$. The detection level of the assay was $10 \mathrm{pg} / \mathrm{ml}$, therefore samples that were not measurable are indicated as $<10 \mathrm{pg} / \mathrm{ml}$. The effect of $10 \mu \mathrm{g} / \mathrm{ml} \mathrm{HA} 122 \mathrm{kDa}$ and $10 \mu \mathrm{g} / \mathrm{ml} \mathrm{HA}>10^{3} \mathrm{kDa}$ are shown. Intra-group comparisons were performed by the Friedman test and, if appropriate (at $\mathrm{p}<0.05$ ), by a paired Wilcoxon rank sum test.

${ }^{*} \mathrm{p}<0.05 v \mathrm{TNF} \alpha$ production in response to LPS $1 \mathrm{ng} / \mathrm{ml}$ without HA added.

$\mathrm{tp}<0.05 v \mathrm{TNF} \alpha$ production in response to LPS $10 \mathrm{ng} / \mathrm{ml}$ without HA added.

sputum cells could therefore contribute to impaired local defence and thus to enhanced bacterial colonisation, as seen in COPD. ${ }^{23}$ However, attention also has to be paid to the potential detrimental role of TNF $\alpha$ in COPD by its contribution to the destruction of lung parenchyma. ${ }^{24}$ Further studies are therefore required to determine the implication of reduced TNF $\alpha$ production by sputum cells ex vivo in COPD patients.

Increasing doses of LPS did not affect TNF $\alpha$ release by sputum cells, which suggests that these cells-in contrast to blood cells-are unresponsive to LPS. Reactivity of sputum cells to PHA and FMLP has been reported, ${ }^{25}{ }^{26}$ indicating that this lack of response is specific for LPS. It is well known that macrophages exposed to suboptimal doses of LPS are rendered tolerant to subsequent exposure to LPS. $^{27}$ We therefore speculate that continuous exposure to bacteria known to colonise airways has made cells tolerant to LPS. Moreover, the discrepancy in viability of sputum cells (which was approximately 60-70\%) compared with blood cells previously shown to be above $95 \%$ (data not shown) could contribute to some of the observed differences and will be the subject of further study.

Significantly enhanced circulating leucocyte numbers were present in COPD patients, as reported previously, ${ }^{28}$ indicating a systemic inflammatory response. Moreover, a correlation was seen between the neutrophil count and $\mathrm{FEV}_{1}$. In this study no enhancement in circulating $\mathrm{TNF} \alpha$ levels was detected in the COPD patients, all of whom had normal BMI. These data are therefore in line with other studies showing unaltered TNF $\alpha$ in the serum of patients of stable weight, whereas enhanced TNF $\alpha$ levels and TNF $\alpha$ production has been shown in patients losing weight. ${ }^{29}{ }^{30}$ No difference in spontaneous and LPS induced TNF $\alpha$ release by whole blood was observed between the study groups. Similarly, Aldonyte $e t a l^{31}$ reported no difference in basal and LPS stimulated TNF $\alpha$ release by monocytes of COPD patients compared with controls. However, in the latter study differences were detected in the production of IL-8 and matrix metalloproteinase 9, indicating changes in production of a specific subset of mediators.

To date, the origin of the systemic inflammation, which is considered to have a potential pathogenic role in other systemic effects of COPD such as nutritional abnormalities and weight loss or skeletal muscle dysfunction," remains poorly understood. This study shows that TNF $\alpha$ production by sputum cells and by blood cells is regulated differently, suggesting that the inflammatory processes in the airways and the circulation are independent. This hypothesis is confirmed by studies showing no correlation between levels of inflammatory mediators in sputum and plasma. ${ }^{72}$ In addition, a recent short term study on the effect of the antiTNF $\alpha$ drug infliximab administered by infusion did not reveal beneficial effects on local inflammatory indices, ${ }^{33}$ further indicating that the local and systemic compartments have to be considered as two separate entities.

Studies on alveolar septal wall remodelling in mild to moderate emphysema show a loss of total tissue, interstitial thickening, and an increased number of interstitial fibroblasts and macrophages. ${ }^{34}$ One interesting compound of the extracellular matrix is HA, a pleiotropic glycosaminoglycan composed of repeating disaccharide units of $\mathrm{N}$-acetyl-D-glucosamine- $\beta$ ( $1 \rightarrow 4$ )-D-glucuronic acid- $\beta(\mathrm{l} \rightarrow 3)$. Accumulating evidence suggests that HA contributes to both homeostasis and disease. ${ }^{35}$ Enhanced circulating levels of HA have been reported in inflammatory disorders. ${ }^{11}$ Its involvement in the pathogenesis of COPD has been suggested by the observation of enhanced levels of $\mathrm{HA}$ in the bronchoalveolar lavage fluid and sputum of these patients. ${ }^{1036}$ Evidence indicates that the biological effects of HA are dependent on its molecular weight, as LMW HA has been shown to be pro-inflammatory and HMW HA to be antiinflammatory. ${ }^{12}$

In contrast to our expectations, the $122 \mathrm{kDa} H A$ fragment used in this study did not induce TNF $\alpha$ release by blood or sputum cells. Stimulating effects of HA fragments of comparable size have been reported for macrophages, ${ }^{12}$ eosinophils, ${ }^{37}$ and renal epithelial cells. ${ }^{38}$ The difference in cell types analysed or the presence of endogenous proteins in the diluted whole blood, such as enzymes degrading HA or protein contaminants such as lysozyme which are able to bind HA, could account for this contradiction. Moreover, both the HMW HA and the $122 \mathrm{kDa}$ HA fragment reduced the LPS induced TNF $\alpha$ release by blood cells. Since HA is reported to bind to the LPS receptor TLR4 on dendritic cells, ${ }^{39}$ we speculate that interaction of HA with TLR4 on blood cells did not lead to cellular activation but hindered LPS induced cellular activation. HA had no effect on sputum cell TNF $\alpha$ production. This could not be due to action of endogenous proteins which were washed away during isolation of cells. Our results did not provide an indication that cells derived from COPD patients showed altered sensitivity towards HA compared with control subjects.

Overall, this study suggests an independent regulation of local versus systemic inflammation in COPD. TNF $\alpha$ production by sputum cells seems to be impaired, which could result in defective local defence. Further studies are needed to 
elucidate these processes further. The extracellular matrix compound HA had an inhibitory effect on LPS induced TNF $\alpha$ release from blood cells which was not different between patients and controls.

\section{ACKNOWLEDGEMENTS}

The authors thank Prof Dr A Schols and Dr E C Creutzberg for expert assistance with the statistical evaluation of the data.

\section{Authors' affiliations}

M A Dentener, R H E Cloots, E F M Wouters, Nutrition and Toxicology Research Institute Maastricht (NUTRIM), Department of Respiratory Medicine, Maastricht University, Maastricht, The Netherlands R Louis, M Henket, Department of Pneumology, CHU Sart-Tilman, University of Liege, Belgium

This study was supported by a grant from the Dutch Asthma Foundation.

Competing interests: EFMW serves as a consultant to GlaxoSmithKline (GSK) and is a member of scientific advisory boards for GSK, Boehringer Ingelheim, Astra Zeneca, Centocor and Numico and received lecture fees from GSK, Astra Zeneca, Boehringer Ingelheim, Pfizer and Numico. He received research grants between 2001 and 2004 from GSK, Astra Zeneca, Boehringer Ingelheim, Centocor and Numico.

\section{REFERENCES}

1 Barnes PJ, Shapiro SD, Pauwels RA. Chronic obstructive pulmonary disease: molecular and cellular mechanisms. Eur Respir J 2003;22:672-88.

2 Di Stefano A, Capelli A, Lusuardi M, et al. Severity of airflow limitation is associated with severity of airway inflammation in smokers. Am J Respir Crit Care Med 1998; 158:1277-85.

3 O'Shaughnessy TC, Ansari TW, Barnes NC, et al. Inflammation in bronchial biopsies of subjects with chronic bronchitis: inverse relationship of CD8+ T lymphocytes with FEV 1 . Am J Respir Crit Care Med 1997;155:852-7.

4 Saetta M, Baraldo S, Corbino L, et al. CD8+ve cells in the lungs of smokers with chronic obstructive pulmonary disease. Am J Respir Crit Care Med 1999; 160:711-7.

5 Hogg JC, Chu F, Utokaparch S, et al. The nature of small-airway obstruction in chronic obstructive pulmonary disease. N Engl J Med 2004;350:2645-53.

6 Keatings VM, Collins PD, Scott DM, et al. Differences in interleukin-8 and tumor necrosis factor-alpha in induced sputum from patients with chronic obstructive pulmonary disease or asthma. Am J Respir Crit Care Med 1996; 153:530-4.

7 Vernooy JH, Kucukaycan M, Jacobs JA, et al. Local and systemic inflammation in patients with chronic obstructive pulmonary disease: soluble tumor necrosis factor receptors are increased in sputum. Am J Respir Crit Care Med 2002; 166:1218-24.

8 Schols AM, Buurman WA, Staal van den Brekel AJ, et al. Evidence for a relation between metabolic derangements and increased levels of inflammatory mediators in a subgroup of patients with chronic obstructive pulmonary disease. Thorax 1996;51:819-24.

9 Agusti AG, Noguera A, Sauleda J, et al. Systemic effects of chronic obstructive pulmonary disease. Eur Respir J 2003:21:347-60.

10 Dentener MA, Vernooy JH, Hendriks S, et al. Enhanced levels of hyaluronan in lungs of patients with COPD: relationship with lung function and local inflammation. Thorax 2005;60:114-9.

11 Majeed M, McQueen F, Yeoman S, et al. Relationship between serum hyaluronic acid level and disease activity in early rheumatoid arthritis. Ann Rheum Dis 2004;63:1166-8.

12 McKee CM, Penno MB, Cowman M, et al. Hyaluronan (HA) fragments induce chemokine gene expression in alveolar macrophages. The role of HA size and CD44. J Clin Invest 1996;98:2403-13.

13 Delvaux $M$, Henket M, Lau L, et al. Nebulised salbutamol administered during sputum induction improves bronchoprotection in patients with asthma. Thorax 2004;59:111-5.
14 Bouma MG, Stad RK, van den Wildenberg FA, et al. Differential regulatory effects of adenosine on cytokine release by activated human monocytes. $\mathrm{J}$ Immunol 1994;153:4159-68.

15 Confalonieri M, Mainardi E, Della Porta $R$, et al. Inhaled corticosteroids reduce neutrophilic bronchial inflammation in patients with chronic obstructive pulmonary disease. Thorax 1998;53:583-5.

16 Culpitt SV, Maziak W, Loukidis S, et al. Effect of high dose inhaled steroid on cells, cytokines, and proteases in induced sputum in chronic obstructive pulmonary disease. Am J Respir Crit Care Med 1999:160:1635-9.

17 Ronchi MC, Piragino C, Rosi E, et al. Role of sputum differential cell count in detecting airway inflammation in patients with chronic bronchial asthma or COPD. Thorax 1996;51:1000-4.

18 Thomas RA, Green RH, Brightling CE, et al. The influence of age on induced sputum differential cell counts in normal subjects. Chest 2004;126:1811-4.

19 Drost EM, Skwarski KM, Sauleda J, et al. Oxidative stress and airway inflammation in severe exacerbations of COPD. Thorax 2005;60:293-300.

20 Bettiol J, Sele J, Henket $M$, et al. Cytokine production from sputum cells after allergenic challenge in IgE-mediated asthma. Allergy 2002;57:1 145-50.

21 Profita M, Chiappara G, Mirabella F, et al. Effect of cilomilast (Ariflo) on TNFalpha, IL-8, and GM-CSF release by airway cells of patients with COPD. Thorax 2003:58:573-9.

22 Patel IS, Roberts NJ, Lloyd-Owen SJ, et al. Airway epithelial inflammatory responses and clinical parameters in COPD. Eur Respir J 2003;22:94-9.

23 Cabello H, Torres A, Celis R, et al. Bacterial colonization of distal airways in healthy subjects and chronic lung disease: a bronchoscopic study. Eur Respir $J$ 1997:10:1137-44.

24 Churg A, Wang RD, Tai $\mathrm{H}$, et al. Tumor necrosis factor-alpha drives $70 \%$ of cigarette smoke-induced emphysema in the mouse. Am J Respir Crit Care Med 2004; 170:492-8.

25 Liu LY, Swensen CA, Kelly EA, et al. The relationship of sputum eosinophilia and sputum cell generation of IL-5. J Allergy Clin Immunol 2000; 106:1063-9.

26 Beeh KM, Beier J, Lerch C, et al. Effects of piclamilast, a selective phosphodiesterase- 4 inhibitor, on oxidative burst of sputum cells from mild asthmatics and stable COPD patients. Lung 2004;182:369-77.

27 Fujihara M, Muroi M, Tanamoto K, et al. Molecular mechanisms of macrophage activation and deactivation by lipopolysaccharide: roles of the receptor complex. Pharmacol Ther 2003;100:171-94.

28 Gan WQ, Man SF, Senthilselvan A, et al. Association between chronic obstructive pulmonary disease and systemic inflammation: a systematic review and a meta-analysis. Thorax 2004;59:574-80.

29 de Godoy I, Donahoe M, Calhoun WJ, et al. Elevated TNF-alpha production by peripheral blood monocytes of weight-losing COPD patients. Am J Respir Crit Care Med 1996;153:633-7.

30 Di Francia M, Barbier D, Mege JL, et al. Tumor necrosis factor-alpha levels and weight loss in chronic obstructive pulmonary disease. Am J Respir Crit Care Med 1994; 150:1453-5.

31 Aldonyte $\mathbf{R}$, Jansson L, Piitulainen $\mathrm{E}$, et al. Circulating monocytes from healthy individuals and COPD patients. Respir Res 2003:4:11.

32 Hurst JR, Wilkinson TM, Perera WR, et al. Relationships among bacteria upper airway, lower airway, and systemic inflammation in COPD. Chest 2005: 127:1219-26.

33 van der Vaart H, Koeter GH, Postma DS, et al. First study of infliximab treatment in patients with chronic obstructive pulmonary disease. Am J Respir Crit Care Med 2005; 172:465-9.

34 Vlahovic G, Russell ML, Mercer RR, et al. Cellular and connective tissue changes in alveolar septal walls in emphysema. Am J Respir Crit Care Med 1999:160:2086-92

35 McDonald J, Hascall VC. Hyaluronan minireview series. J Biol Chem 2002;277:4575-9.

36 Song WD, Zhang AC, Pang $Y Y$, et al. Fibronectin and hyaluronan in bronchoalveolar lavage fluid from young patients with chronic obstructive pulmonary diseases. Respiration 1995;62:125-9.

37 Ohkawara Y, Tamura G, Iwasaki T, et al. Activation and transforming growth factor-beta production in eosinophils by hyaluronan. Am J Respir Cell Mol Biol 2000;23:444-51.

38 Oertli B, Beck-Schimmer B, Fan X, et al. Mechanisms of hyaluronan-induced up-regulation of ICAM-1 and VCAM- 1 expression by murine kidney tubular epithelial cells: hyaluronan triggers cell adhesion molecule expression through a mechanism involving activation of nuclear factor-kappa $B$ and activating protein-1. J Immunol 1998;161:3431-7.

39 Termeer C, Benedix F, Sleeman J, et al. Oligosaccharides of hyaluronan activate dendritic cells via toll-like receptor 4. J Exp Med 2002;195:99-111. 